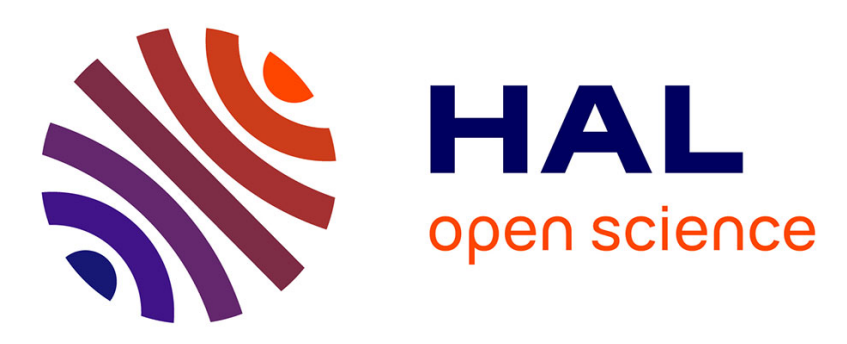

\title{
Regional Rainfall Thresholds for Shallow and Deep-Seated Mass Movements Triggering in the South Eastern French Alps
}

Alexandre Remaître, Jean-Philippe Malet

\section{- To cite this version:}

Alexandre Remaître, Jean-Philippe Malet. Regional Rainfall Thresholds for Shallow and Deep-Seated Mass Movements Triggering in the South Eastern French Alps. Advancing Culture of Living with Landslides, Springer International Publishing, pp.183 - 192, 2017, 10.1007/978-3-319-53485-5_20 . hal-03075743

\section{HAL Id: hal-03075743 \\ https://hal.science/hal-03075743}

Submitted on 8 Jan 2022

HAL is a multi-disciplinary open access archive for the deposit and dissemination of scientific research documents, whether they are published or not. The documents may come from teaching and research institutions in France or abroad, or from public or private research centers.
L'archive ouverte pluridisciplinaire HAL, est destinée au dépôt et à la diffusion de documents scientifiques de niveau recherche, publiés ou non, émanant des établissements d'enseignement et de recherche français ou étrangers, des laboratoires publics ou privés. 


\title{
Regional Rainfall Thresholds for Shallow and Deep-Seated Mass Movements Triggering in the South Eastern French Alps
}

\author{
Alexandre Remaître and Jean-Philippe Malet
}

\begin{abstract}
The main objective of this work is to propose hydro-meteorological thresholds for the triggering of shallow (slides, debris/mud flows) and deep-seated mass movements within a vast area of the South-East French Alps (Queyras, Ubaye, Tinée) characterized by various rainfall patterns. For this purpose, we exploit a landslide catalogue (containing more than 600 events) for the period 1928-2014 describing the date (and sometimes the hours) of occurrence, the type of mass movement, the geographical location and the nearest meteorological station. Rainfall data are available for 36 stations. A statistical analysis of rainfall conditions associated to triggering of shallow mass movements at various time scales (yearly, monthly, daily and hourly) reveals that rainfall thresholds are spatially highly variable.
\end{abstract}

\author{
Keywords \\ Triggering • Rainfall patterns $・$ Rainfall thresholds
}

\section{Introduction}

Rainfall is worldwide a recognized trigger of landslides. Numerous studies were conducted in order to define relationships between rainfall and triggering or reactivation of landslides (Corominas 2000; Iverson 2000; Wieczorek and Glade 2005, Godt et al. 2006; Cannon et al. 2008). Hydrological triggering of landslides can be divided in three general types: (1) development of local perched water tables in the subsoil leading to shallow slides and gravitational flows, (2) long-lasting rise in permanent water tables leading to the triggering of deep-seated slope instabilities, and (3) intense runoff causing debris flows. Types (1) and (3) are usually observed for high rainfall intensity events (hourly and daily rainfall) associated to heavy storms; type (2) is usually observed through increasing water content in the

\footnotetext{
A. Remaître ( $\bowtie) \cdot$ J.-P. Malet Institut de Physique du Globe de Strasbourg, CNRS UMR 7516, Ecole et Observatoire Des Sciences de la Terre, Université de Strasbourg, 5 rue Descartes, 67084 Strasbourg, France e-mail: a.remaitre@unistra.fr
}

subsoil due to antecedent rainfalls (weekly or monthly rainfall) and/or massive snowmelt.

Many investigations have been carried out to determine the amount of precipitation needed to trigger slopes failures. A large state-of-the-art on rainfall thresholds can be found in Guzzetti et al. (2007, 2008). A threshold can be defined as the minimum or maximum level of some quantity needed for a process to take place (trigger) or a state of change (landslide reactivation). For rainfall-induced landslides, thresholds may be defined in terms of rainfall, soil moisture or hydrological conditions that, when reached or exceeded, are likely to trigger a movement (Guzzetti et al. 2007). Usually rainfall thresholds are defined using conceptual or physically process-based models (Crozier 1999; Glade et al. 2000; Crosta and Frattini 2003; Casadei et al. 2003; Aleotti 2004) or through statistical analyses (Caine 1980; Corominas and Moya 1999; Floris and Bozzano 2008; Li et al. 2011). The large variety of landslides (Cruden and Varnes 1996; Hungr et al. 2001) and the extreme variety of climatic conditions leading to the triggering or the reactivation of a landslides lead to a regional definition of relationships between landslide occurrence and associated climatic conditions. Most of 
the rainfall thresholds for the possible occurrence of a given landslide are valid only at a local or a regional scale (Brunetti et al. 2010) and are strongly correlated to local physiographic factors (e.g. landcover, topography, human influence).

The purpose of this work is to document the relationships between the triggering of two types of mass movements (debris flows and deep-seated landslides) and different patterns of rainfall at various temporal scales for the Southeast French Alps. For this purpose, we exploit a landslide catalogue and rainfall data to propose rainfall thresholds for both types of landslides.

\section{General Overview of the Study Area}

The study area is the Southeast part of the French Alps and consists of three large catchments (Queyras, Ubaye and Tinée, from the North to the South). Elevation ranges from sea level, along the Mediterranean coast, to more than $3500 \mathrm{~m}$. Queyras and Ubaye exhibit highest elevations and steepest slopes while the Subalps of the Tinée area is divided into a series of massifs separated by deep valleys. South to Utelle (Fig. 1), the relief becomes softer towards the Mediterranean Sea.

The structural settings control the morphology of the area. Sedimentary rocks crop out in the entire area (Fig. 1) and consist mainly of marls and limestone within the Subalpine chain and flysch and sandstones within thrust sheets units. In the North, the "Queyras Nappe", made of high-pressure metamorphic Mesozoic slates (blue- to green-schist facies), covers continental crustal rocks. "Ubaye valley" has extensive outcrops of autochthonous blue-black shales, known as Callovo-Oxfordian black marls (Maquaire et al. 2003), containing the occasional limestone bands. Black marls are overlain by Embrunais-Ubaye sheet thrusts which are made of calcareous sandstones and flyschs. The Tinée area is formed by folding and thrusting of Mesozoic limestones and shales together with the Tertiary foreland basin sediments. The eastern part of the Tinée is mostly made of plutonic rocks (external crust unit, Fig. 1).

In the three areas, weathering processes are very active: thick debris talus, moraines talus, landslide deposits, terrace fluvial and torrential deposits cover most of the hummocky hillsides. Summits are mostly made of bare rocks surrounded with large scree talus. Landslides of all types are abundant in the area. Landslide abundance and pattern vary spatially, and are controlled by the relative position of sedimentary and tectonic discontinuities, by the relative abundance of hard versus weak or soft rocks, and by the presence and attitude of permeable and impermeable layers (Flageollet et al. 1999; Maquaire et al. 2003; Cossart et al. 2008; Zerathe et al. 2014).
From a climatic point of view, Queyras and Ubaye areas are located in the dry intra-Alpine zone (Fig. 2). Its climate is characterized by (1) a mountain influence with a marked inter-annual rainfall variability (e.g. $667 \pm 400 \mathrm{~mm}$ over the period 1928-2014 for the Barcelonnette station) and 130 days of freezing per year, (2) a continental influence with significant daily thermal amplitudes $\left(>20^{\circ}\right)$ and numerous freeze-thaw cycles and (3) heavy spring rains on melting thick snow layers which can also lead to high discharges. The Tinée area climate is much more humid (900$1300 \mathrm{~mm}$ per year) and is characterized by a typical annual cycle with most of precipitation in autumn (about 35\% of yearly precipitation) and a dry summer period. The mean temperature is slightly higher than the two other areas. This is particularly true in winter, with a lower number of freeze-thaw cycles and a thinner snow cover.

For the three areas, a strong Mediterranean influence leads to violent summer rainstorms yielding more than $50 \mathrm{~mm} \mathrm{~h}^{-1}$ on occasion (Turkington et al. 2016).

\section{Landslides Catalogues, Meteorological Data and Methodology}

\section{Historical Landslide Catalogue}

For landslides, the study builds up on existing catalogues of Flageollet et al. (1999) and Remaître and Malet (2010), which have been completed by a catalogue of RTM Service (Restauration des Terrain en Montagne) which has collected since 1880 a catalogue of historical landslides for the entire French Alps. The RTM catalogue is built from a systematic field reporting. The catalogue has been further completed with various data (technical reports, monographs, scientific papers and local inhabitants' interviews). Events reported in the catalogue correspond usually to landslides that resulted in damage, affecting buildings or roads, and were located near towns and villages. Nevertheless, this catalogue is probably not complete; some landslides are not listed because (i) they were not observed or (ii) they did not cause any damages.

The analysed catalogue consists of 668 historical landslides and debris flows for the period 1930-2014 (Fig. 3). For each event, the catalogue includes: (1) the location, (2) the precise time, date or period of failures, (3) the landslide type, (4) the rainfall condition that resulted in slope failures, including the daily rainfall, the antecedent rainfall for various periods and for some stations the total event rainfall, the rainfall duration, the mean rainfall intensity and peak rainfall intensities, and (5) the affected rock types and/or superficial formations. Analysis of the geographical distribution of the landslide events listed in the catalogue revealed a geographical bias, with the majority of the 


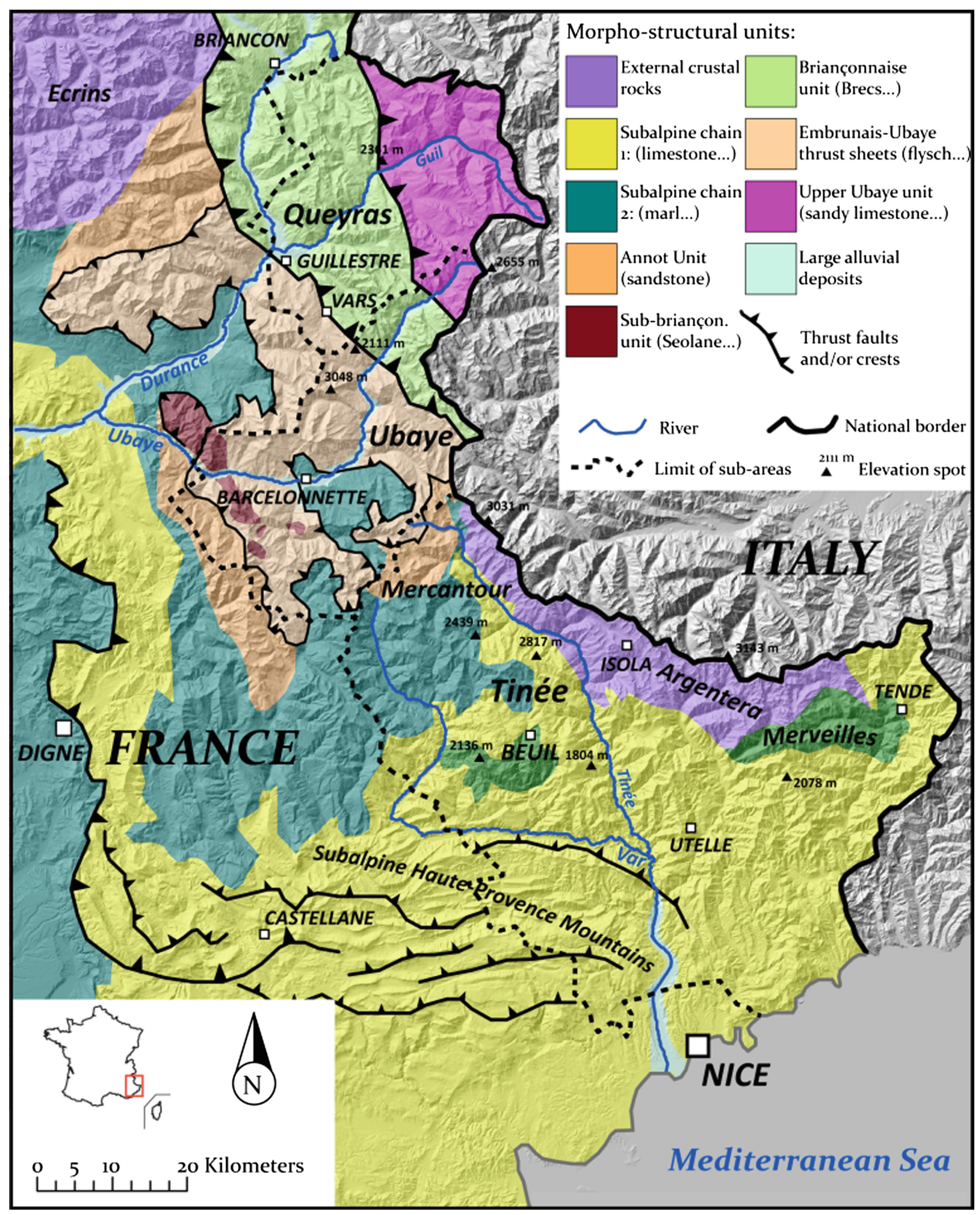

Fig. 1 Geological sketch of the South French Alps 


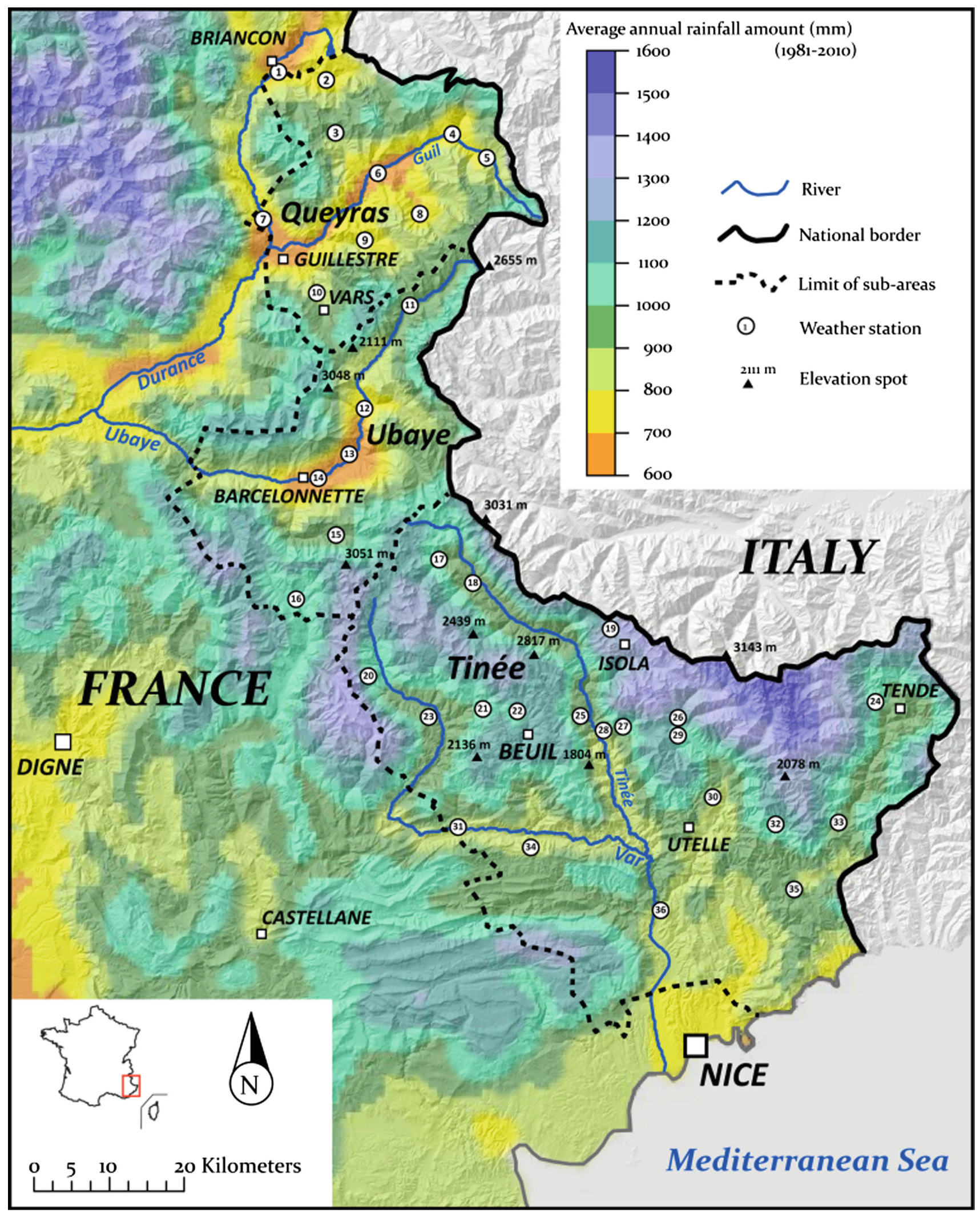

Fig. 2 Mean annual precipitation (MAP) map of the South East French Alps (data from the website of Météo-France: http://www.meteofrance.fr/) and location of raingauges within the study area. Raingauge ID can be found in Table 1 


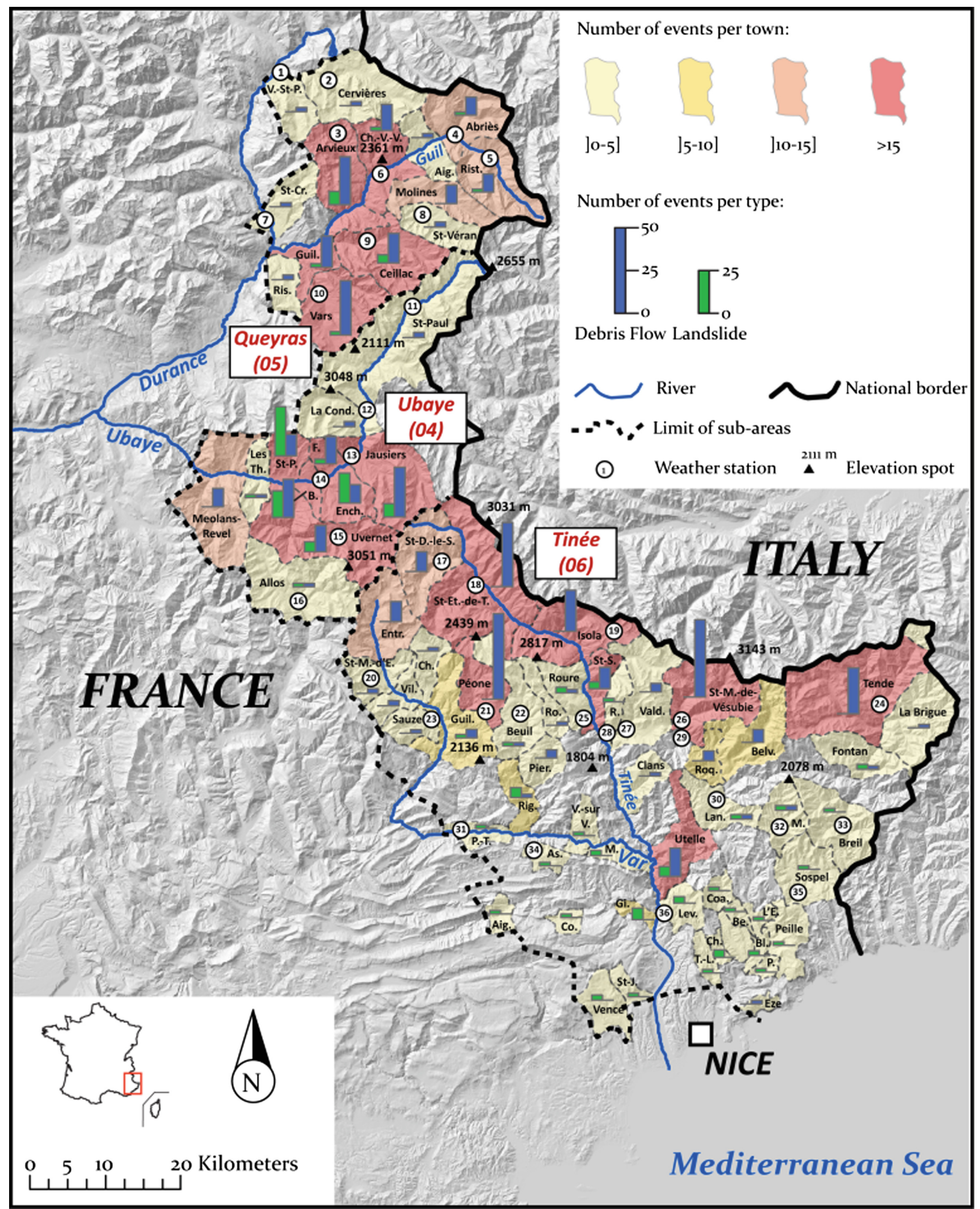

Fig. 3 Debris-flow and landslide database for the South French Alps 
slow-moving landslide events respectively in the Ubaye area $(45 \%)$ and the Tinée area $(48 \%)$.

\section{Meteorological Data}

We used 36 meteorological stations (Table 1), 10 for the Queyras area, 6 for the Ubaye area and 20 for the Tinée area.

Information on rainfall events was cross-checked in order to identify duplicate landslide events, landslide events for which rainfall information was not considered as relevant or sufficiently documented. These landslide events were excluded from the catalogue.

At the end of the review process, we build two catalogues for two different objectives: (i) a catalogue of 668 events (542 shallow mass movements (e.g. debris flows) and 126 deep-seated mass movements (e.g. landslides)) for the analysis of antecedent precipitation at various time scales (from 1 to 180 days) with daily rainfall data (1930-2014); (ii) a catalogue of 259 events (186 debris flows and 73 landslides) for the identification of rainfall threshold through the analysis of hourly rainfall data (1998-2014).

\section{Results and Analysis}

\section{Historical Landslide Time Series: Seasonal and Geographical Repartition}

The seasonal occurrence of mass movements exhibits a clear distinction between debris flows and deep-seated landslides for the entire study area (Fig. 4a): debris-flow occurrences show a clear activity peak in June, July and August. In contrast, mudslides occurrences show two peaks in spring (March, April and May) and autumn (October and November).

Comparison of the seasonal distribution of landslide events for the three areas is instructive (Fig. 4b, c). If the distribution is quite similar for Ubaye and Queyras (especially for debris flows), the Tinée area exhibits a different pattern. In the Tinée area, the period of debris-flow activity is much longer and extends from June to November. This must be put in relation with the peculiarity of the monthly distribution of rainfall in the Tinée where October and November are the wettest months. A similar observation can be made for the deep-seated landslides distribution: in Ubaye, most of the landslides occur during spring (snow melt and seasonal rainfall). In Tinée, a majority of landslide occurs in autumn with long (at least $24 \mathrm{~h}$ ) and sometimes intense rainfall episodes.

\section{Daily Rainfall and Antecedent Rainfall Analysis}

Daily rainfall versus antecedent rainfall analysis is of primary interest for landslides hazard assessment. When using antecedent rainfall measurements to estimate landslide occurrence, a key difficulty is the definition of the period over which to accumulate precipitation. Usually, such analyses revealed a significant scatter according to the considering period (e.g. Guzzeti et al. 2007). In this work, several periods have been investigated: $180,150,120,90,60,30,14,7,6,5,4,3$ and 2 days before the event. Figure 5 plots all the considered antecedent rainfall periods for all the events.

Once again, a clear distinction is observed for both types of mass movements. Most of the debris flows occurs after a 7-day dry period while deep-seated landslides triggering or reactivation needs at least $40 \mathrm{~mm}$ of antecedent precipitation during the last 7 days. For a larger time scale, results show that debris flows never occurred when the antecedent rainfall for the 180-days period exceeds $410 \mathrm{~mm}$. On the contrary, antecedent rainfall for a 180-days period has to be at least $205 \mathrm{~mm}$ in order to trigger a deep-seated landslide. But these facts have to be put in relationship with the climatic characteristics of each study area and also the seasonal occurrence of both types of events: summer for debris flows, and spring and autumn for deep-seated landslides.

\section{Intensity-Duration of Rainfall Events Associated to Rainfall-Induced Mass Movement (Deep-Seated Landslide and Debris Flow)}

259 events (186 debris flows and 73 deep-seated landslides) were used for this analysis. Figure 6 presents the scatter plot of the available Intensity-Duration (ID) data. A clear distinction concerning the mean rainfall intensity appears for the two types of landslides: for debris flows, the mean intensity ranges from 1.4 to $27.8 \mathrm{~mm} \mathrm{~h}^{-1}$, and the total duration of the rainfall event ranges from 1 to $57 \mathrm{~h}$. For deep-seated landslides, the mean intensity ranges from 0.5 to $6.4 \mathrm{~mm} \mathrm{~h}^{-1}$, and the total duration of the event ranges from 8 to $38 \mathrm{~h}$.

Some authors (e.g. Godt et al. 2006; Cannon et al. 2008) have suggested that for the purposes of threshold estimation, and in order to better constrain the threshold within a range of durations, the storms should be characterized using both mean intensities and also peak intensities for a selection of durations. From a general point of view, the general shape of the curves of peak intensities (Fig. 7) are quite similar, and show a clear descending trend of the minimum level of average rainfall intensity with increasing rainfall duration. 
Table 1 Meteorological station characteristics. M.A.P. is the mean annual precipitation index (the location of the stations can be found at Fig. 3)

\begin{tabular}{|c|c|c|c|c|c|c|}
\hline \multirow[t]{2}{*}{ ID Station name } & \multirow[t]{2}{*}{ Area } & \multirow[t]{2}{*}{ Elevation } & \multicolumn{2}{|c|}{ Daily date } & \multirow{2}{*}{$\begin{array}{l}\text { Hourly } \\
\text { Start }\end{array}$} & \multirow{2}{*}{$\begin{array}{l}\text { M.A.P. } \\
\mathrm{mm}\end{array}$} \\
\hline & & & Start & End & & \\
\hline 1. VILLAR ST PANCRACE & Queyras & 1310 & 2003 & & $20 / 08 / 2003$ & $600-700$ \\
\hline 2. CERVIERES & Queyras & 1615 & 1933 & & & $700-800$ \\
\hline 3. ARVIEUX & Queyras & 1825 & 1947 & & $10 / 07 / 2007$ & $900-1000$ \\
\hline 4. ABRIES & Queyras & 1560 & 1931 & & & $700-800$ \\
\hline 5. RISTOLAS & Queyras & 1670 & 2004 & & 05/10/2004 & $800-900$ \\
\hline 6. CHATEAU-VILLE-VIEILLE & Queyras & 1355 & 1932 & & & $600-700$ \\
\hline 7. ST CREPIN & Queyras & 906 & 2006 & & $30 / 08 / 2006$ & $700-800$ \\
\hline 8. ST VERAN & Queyras & 2006 & 1929 & & & $700-800$ \\
\hline 9. CEILLAC & Queyras & 1665 & 1931 & & & $700-800$ \\
\hline 10. VARS & Queyras & 1850 & 1931 & 2000 & & $800-900$ \\
\hline 11. ST PAUL & Ubaye & 1908 & 1971 & & & $900-1000$ \\
\hline 12. LA CONDAMINE & Ubaye & 1325 & 1955 & 2004 & & $700-800$ \\
\hline 13. J AUSIE RS-ST ANNE & Ubaye & 1240 & 1960 & & & $600-700$ \\
\hline 14. BARCELONNETTE & Ubaye & 1155 & 1928 & & 03/02/1998 & $600-700$ \\
\hline 15. UVERNET FOURS & Ubaye & 1660 & 1955 & & & $900-1000$ \\
\hline 16. ALLOS & Ubaye & 1400 & 1971 & & $26 / 05 / 2010$ & $\begin{array}{l}1000- \\
1100\end{array}$ \\
\hline 17. SAINT-DALMAS-LE-SELVAGE & Tinée & 1880 & 1931 & 2002 & & $\begin{array}{l}1000- \\
1100\end{array}$ \\
\hline 18. ST ETIENNE DE TINEE_SAPC & Tinée & 1150 & 1952 & & $29 / 03 / 2007$ & $900-1000$ \\
\hline 19. ISOLA 2000 & Tinée & 1912 & 1972 & & & $\begin{array}{l}1200- \\
1300\end{array}$ \\
\hline $\begin{array}{l}\text { 20. ST MARTIN } \\
\text { D'ENTRAUNES_SAPC }\end{array}$ & Tinée & 1642 & 2007 & & 05/07/2007 & $\begin{array}{l}1000- \\
1100\end{array}$ \\
\hline 21. PEONE & Tinée & 1784 & 1951 & & $20 / 11 / 2002$ & $\begin{array}{l}1000- \\
1100\end{array}$ \\
\hline 22. BEUIL-OBS & Tinée & 1460 & 1928 & & & $\begin{array}{l}1000- \\
1100\end{array}$ \\
\hline 23. GUILLAUME-OBS & Tinée & 803 & 1931 & 2014 & & $900-1000$ \\
\hline 24. TENDE-OBS & Tinée & 898 & 1952 & & $01 / 01 / 1993$ & $\begin{array}{l}1000- \\
1100\end{array}$ \\
\hline 25. ST-SAUVEUR-SUR-TINEE & Tinée & 487 & 1932 & 2007 & & $900-1000$ \\
\hline 26. ST-MARTIN-DE-VESUBIE-OBS & Tinée & 994 & 1950 & & & $\begin{array}{l}1100- \\
1200\end{array}$ \\
\hline 27. VALDEBLORE & Tinée & 1058 & 1936 & 2001 & & $\begin{array}{l}1000- \\
1100\end{array}$ \\
\hline 28. RIMPLAS_SAPC & Tinée & 1130 & 2006 & & $15 / 02 / 2007$ & $900-1000$ \\
\hline 29. SAINT MARTIN VESUBIE_SAPC & Tinée & 899 & 1950 & & $01 / 11 / 2013$ & $\begin{array}{l}1000- \\
1100\end{array}$ \\
\hline 30. LANTCSQUE_SAPC & Tinée & 550 & 1932 & & $27 / 12 / 2006$ & $800-900$ \\
\hline 31. PUGET THENIERS_SAPC & Tinée & 442 & 1931 & & $02 / 12 / 1997$ & $800-900$ \\
\hline 32. MOULINET & Tinée & 817 & & & & $\begin{array}{l}1000- \\
1100\end{array}$ \\
\hline 33. BREIL SUR ROYA & Tinée & 319 & 1931 & & $09 / 01 / 1993$ & $900-1000$ \\
\hline 34. ASCROS & Tinée & 1173 & 1987 & & $01 / 01 / 1993$ & $800-900$ \\
\hline 35. SOSPEL & Tinée & 843 & 1928 & & $04 / 11 / 2004$ & $900-1000$ \\
\hline 36. LEVENS & Tinée & 691 & 1933 & & $16 / 05 / 2008$ & $800-900$ \\
\hline
\end{tabular}


Fig. 4 Monthly distribution of historical mass movements for the period 1930-2014. a Monthly distribution of debris flows and deep-seated landslides for the entire area. b Monthly distribution of debris flows per sub-areas. c Monthly distribution sub-areas of deep-seated landslides per

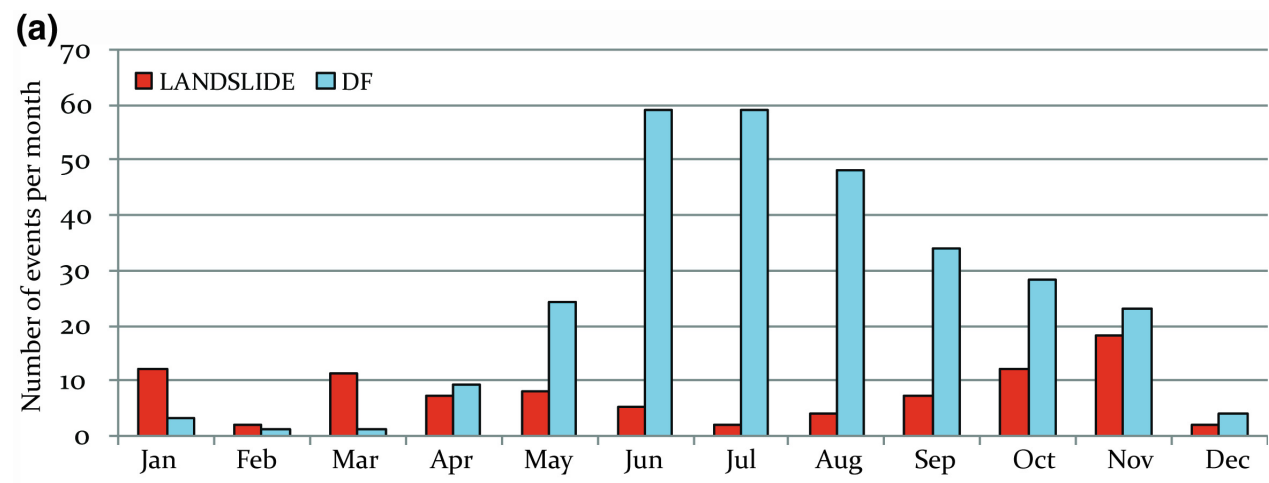

(b)

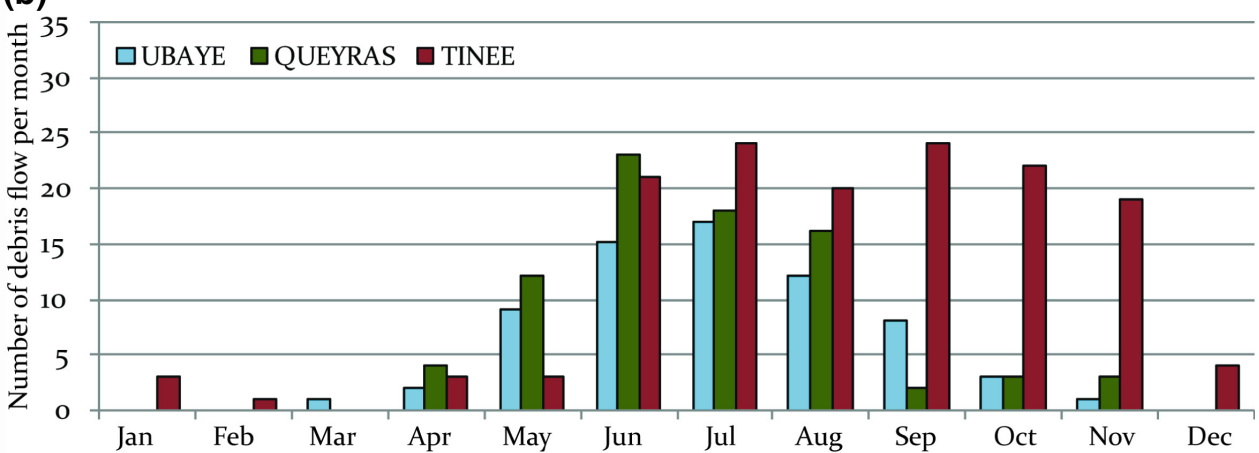

(c)

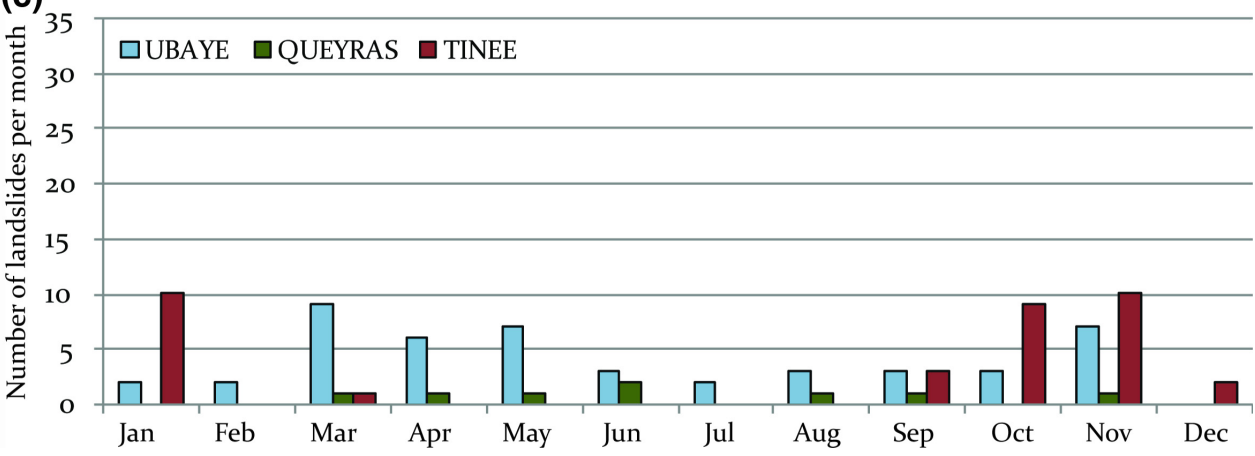

Fig. 5 Antecedent cumulative rainfall for debris flows and deep-seated landslides in the three study areas for different periods: 180, 150, 120, 90, 60, 30, 14, 7, $6,5,4,3$ and 2-days periods before the event

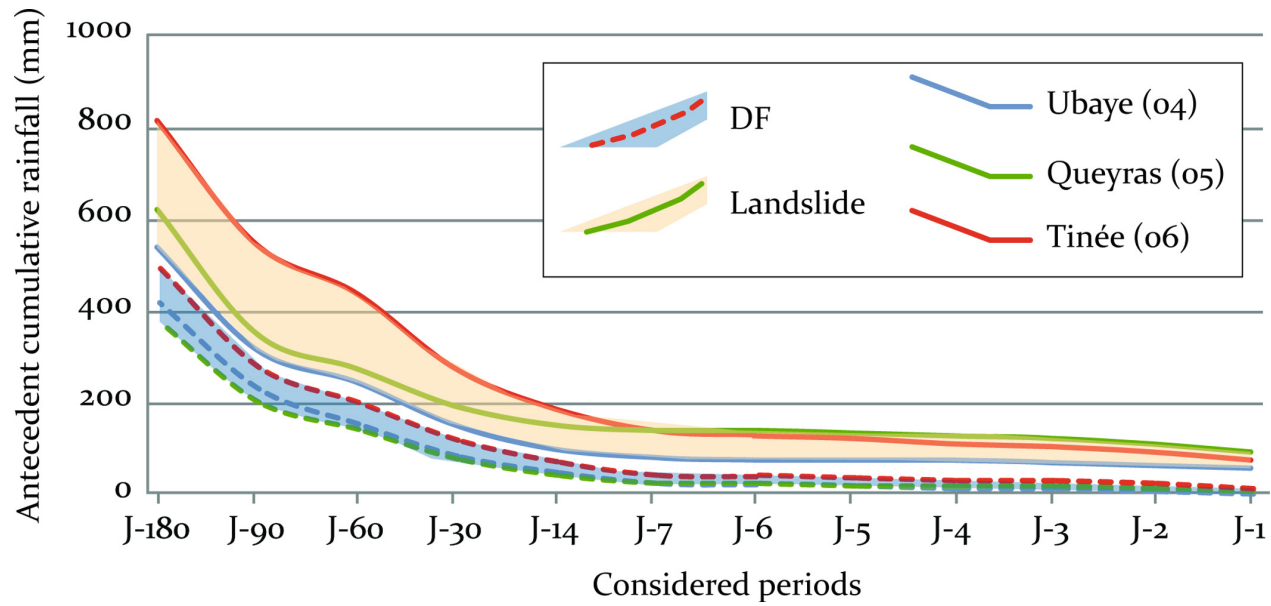




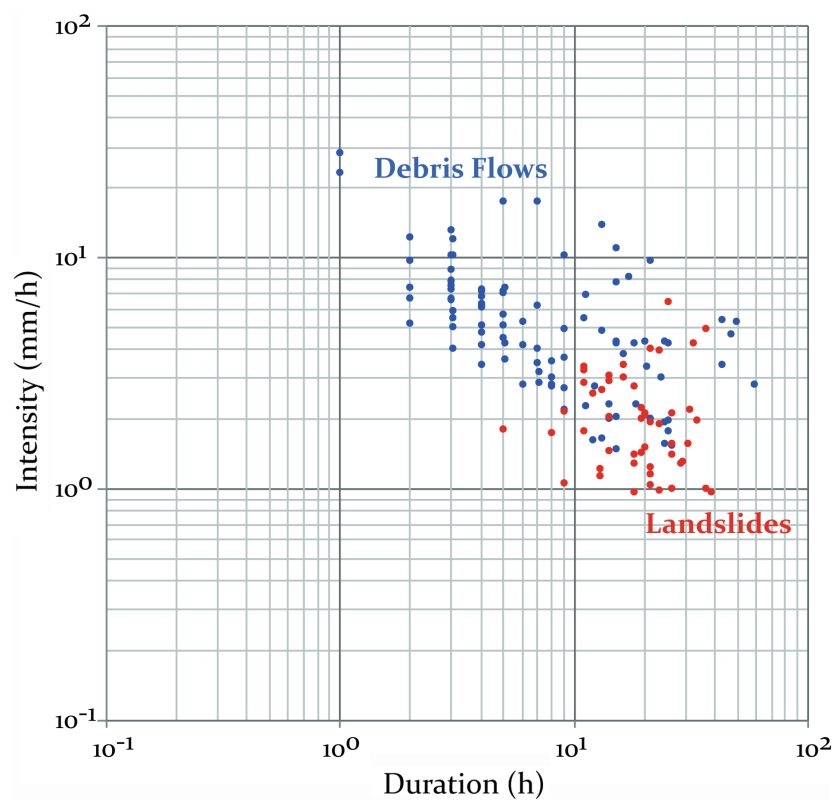

Fig. 6 Mean rainfall intensity versus event total duration for debris-flows (in blue) and deep-seated landslides (in red) for the Southeast French Alps

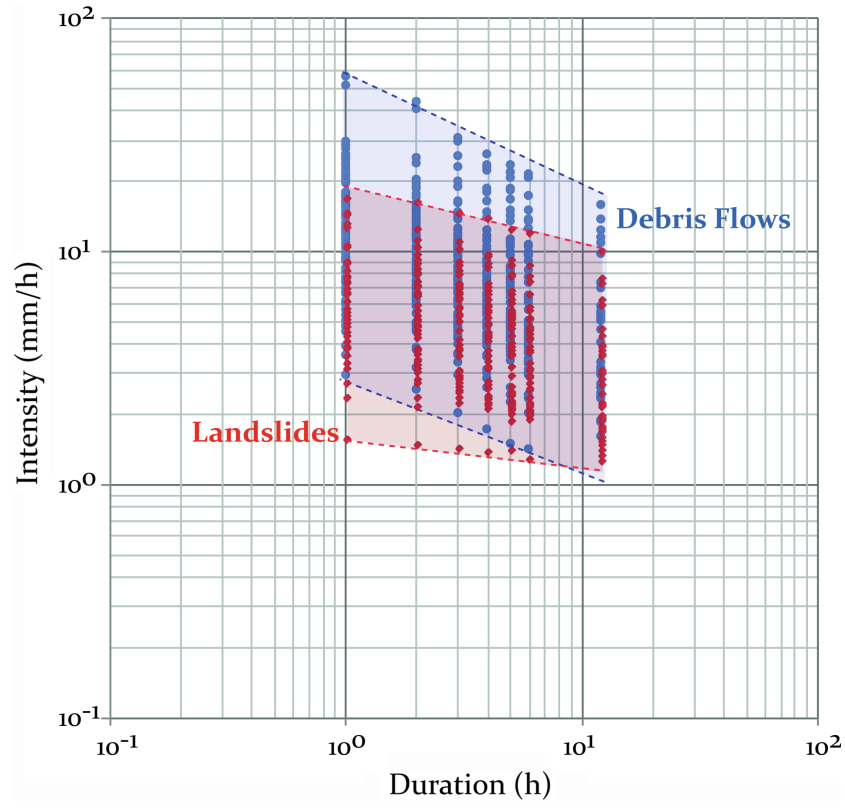

Fig. 7 Peak rainfall intensity versus event total duration for debris-flows (in blue) and deep-seated landslides (in red) for South Eastern French Alps

Plotted peak intensities show a similar trend than observed on Fig. 6; a clear distinction between rainfall patterns concerning debris flow or deep-seated landslides can be observed: Events characterized by high rainfall intensity

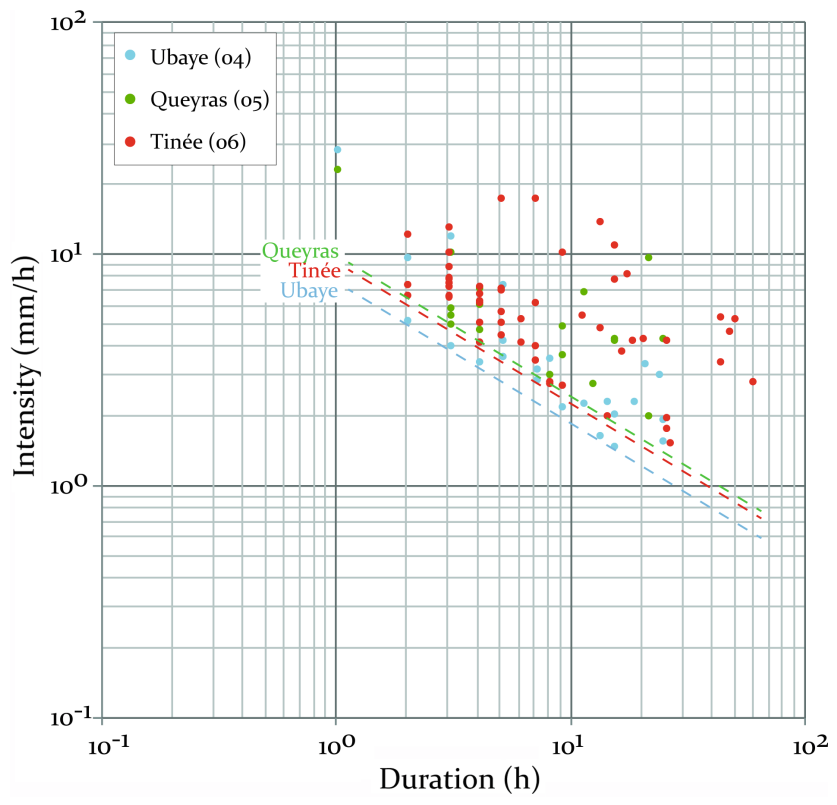

Fig. 8 Mean rainfall intensity versus event total duration for debris-flows in the three sub-areas: Queyras (green dots), Ubaye (blue dots) and Tinée (red dots)

(average and peak) and short episode duration (e.g., mostly the result of localized convective storms) will trigger mostly debris flows in relatively permeable soils (e.g., moraines, scree or poorly sorted slope deposits).

Long rainfall periods characterized by low to moderate average and peak rainfall intensity (e.g. the result of multiple and successive storms during a period of several weeks or months) can trigger or reactivate shallow and deep-seated landslides in low permeability soils and rocks (e.g., black marls).

Comparing rainfall thresholds for the three study areas was only pertinent for debris flows. Indeed, lack of deep-seated landslide events in the Queyras area makes the comparison irrelevant for such kind of landslides. Figure 8 plots the ID relationship for debris flows per sub-areas.

Inspection of Fig. 8 confirms the linear scaling of the minimum level of rainfall intensity likely to trigger debris flows in the range of duration from 1 to $58 \mathrm{~h}$ for the three sub-areas. Comparison of the threshold curves reveals that the minimum levels of rainfall intensity likely to generate debris flows in the three areas are different. If Queyras and Tinée exhibit a very similar threshold, the ID threshold for the Ubaye area is slightly lower. This could be put in relation with the geomorphological settings of the Ubaye area, where active erosion processes provide available sediments more frequently and/or in a larger quantity (Remaitre et al. 2011; Turkington et al. 2016). 


\section{Conclusion}

At the monthly scale, a clear distinction can be observed for debris flow (strong storm associated to a 7-day dry period) and deep-seated landslides (at least $40 \mathrm{~mm}$ of antecedent precipitation during the last 7 days and at least $200 \mathrm{~mm}$ during the last 180 days).

At the hourly scale, the ID relationship for debris flows for the three areas were built and show a similarity for the three areas even in the Ubaye area exhibits a lower ID threshold. These results could be improved through the analysis of rainfall-radar data. Since 20123 on-site meteorological radars were installed in the South Eastern French Alps. The analysis of these radar data will (1) reduce the uncertainty of rainfall intensities calculation and (2) increase significantly our knowledge about the spatial distribution of the rainfalls and the preferential paths of storm cells and rainfalls fields.

Acknowledgements This research was funded through the French ANR Project 'SAMCO', the European Project FP7 'SafeLand: Living with landslide risk in Europe' (2009-2012) and through the European Project FP7 ERA-NET CIRCLE 'Changing Risks' project.

\section{References}

Aleotti P (2004) A warning system for rainfall-induced shallow failures. Eng Geol 73:247-265

Brunetti MT, Peruccaci S, Rossi M, Luciani S, Valigi D, Guzzetti F (2010) Rainfall thresholds for the possible occurrence of landslides in Italy. Nat Hazards Earth Syst Sci 10:447-458

Caine N (1980) The rainfall intensity-duration control of shallow landslides and debris flows. Geogr Ann 62A(1-2):23-27

Cannon SH, Gartner JE, Wilson RC, Bowers JC, Laber JL (2008) Storm rainfall conditions for floods and debris flows from recently burned areas in southwestern Colorado and southern California. Geomorphology 96:250-269

Casadei M, Dietrich WE, Miller L (2003) Testing a model for predicting the timing and location of shallow landslide initiation in soil-mantled landscapes. Earth Surf Proc Land 28:925-950

Corominas J (2000) Landslides and climate. In: Bromhead E, Dixon N, Ibsen ML (eds.) 8th International symposium on landslides, Cardiff, pp 1-33

Corominas J, Moya J (1999) Reconstructing recent landslide activity in relation to rainfall in the Llobregat River basin, Eastern Pyrenees, Spain. Geomorphology 30:79-93

Cossart E, Braucher R, Fort M, Bourlès DL, Carcaillet J (2008) Slope instability in relation to glacial debuttressing in alpine areas (Upper Durance catchment, southeastern France): Evidence from field data and $10 \mathrm{Be}$ cosmic ray exposure ages. Geomorphology 95(1-2):3-26

Crosta GB, Frattini P (2003) Distributed modelling of shallow landslides triggered by intense rainfall. Nat Hazards Earth Syst Sci 3:81-93
Crozier MJ (1986) Landslides: causes, consequences and environment. Croom Helm, London

Crozier MJ (1999) Prediction of rainfall-triggered landslides: a test of the antecedent water status model. Earth Surf Proc Land 24:8 $25-833$

Cruden DM, Varnes DJ (1996) Landslide types and processes. In: Turner AK, Shuster RL (eds) Landslides: investigation and mitigation. Transportation research board special report no. 247, pp 36-75

Flageollet J-C, Maquaire O, Martin B, Weber D (1999) Landslides and climatic conditions in the Barcelonnette and Vars basins (Southern French Alps, France). Geomorphology 30:65-78

Floris M, Bozzano F (2008) Evaluation of landslide reactivation: a modified rainfall threshold model based on historical records on rainfall and landslides. Geomorphology 94:40-57

Glade T, Crozier MJ, Smith P (2000) Applying probability determination to refine landslide-triggering rainfall thresholds using an empirical "antecedent daily rainfall model". Pure Appl Geophys 157(6-8):1059-1079

Godt JW, Baum RL, Chleborad AF (2006) Rainfall characteristics for shallow landsliding in Seattle, Washington. USA Earth Surf Proc Land 31:97-110

Guzzetti F, Peruccaci S, Rossi M, Stark CP (2007) Rainfall thresholds for the initiation of landslides in central and southern Europe. Meteorol Atmos Phys 98:239-267

Guzzetti F, Peruccaci S, Rossi M, Stark CP (2008) The rainfall intensity-duration control of shallow landslides and debris flows: an update. Landslides 5(1):3-17

Hungr O, Evans SG, Bovis M, Hutchinson JN (2001) Review of the classification of landslides of the flow type. Environ Eng Geosci 7:221-238

Iverson RM (2000) Landslide triggering by rain infiltration. Water Resour Res 36(7):1897-1910

Li C, Ma T, Zhu X, Li W (2011) The power-law relationship between landslide occurrence and rainfall level. Geomorphology 130: 221-229

Maquaire O, Malet J-P, Remaître A, Locat J, Klotz S, Guillon J (2003) Instability conditions of marly hillslopes: towards landsliding and gullying? The case of the Barcelonnette Basin. South East France Eng Geol 70(1-2):109-130

Remaitre A, Malet J-P (2010) The effectiveness of torrent check dams to control channel instability: example of debris-flow events in clay shales. In: Garcia CC, Lenzi MA (eds) Check dams, morphological adjustments and erosion control in torrential streams. Nova Science Publishers Inc, New York, pp 211-237

Remaitre A, Malet J-P, Maquaire O (2011) Geomorphology and mechanics of debris flows with high entrainment rate: a case study in the South French Alps. C.R. Géosciences 343(11-12):777-794

Turkington T, Remaître A, Ettema J, Hussin HY, van Westen C (2016) Assessing debris flow activity in a changing climate. Clim Change 137(1):293-305

Wieczorek GF, Glade T (2005) Climatic factors influencing occurrence of debris flows. In: Jakob M, Hungr O (eds) Debris flow hazard and related phenomena. Springer, Berlin, pp 325-362

Zerathe S, Lebourg T, Braucher R, Bourlès D (2014) Mid-Holocene cluster of large-scale landslides revealed in the Southwestern Alps by $36 \mathrm{Cl}$ dating. Insight on an Alpine-scale landslide activity. Quat Sci Rev 90:106-127 